\title{
INVENTARISASI DATA IRIGASI MENGGUNAKAN SISTEM INFORMASI GEOGRAFI UNTUK MENDUKUNG PEMBAGIAN DEBIT AIR
}

\author{
Agus Qomaruddin Munir ${ }^{1}$ \\ ${ }^{1}$ Teknologi Informasi Fakultas Sains dan Teknologi Universitas Respati Yogyakarta \\ Jln. Laksda Adisucipto Km 6.3, Depok - Sleman Kota Yogyakarta \\ ${ }^{1}$ agusqmnr@ respati.ac.id
}

\begin{abstract}
Abstrak - Kabupaten Sleman merupakan salah satu wilayah propinsi Daerah Istimewa Yogyakarta yang dijadikan sebagai daerah lumbung padi. Hal ini menjadi salah satu potensi di bidang pertanian untuk mencukupi kebutuhan pangan bagi penduduk di wilayah sekitarnya. Hasil panen di wilayah kabupaten Sleman yang terbesar salah satunya adalah padi. Pengembangan dan pemeliharaan padi di area persawahan di Kabupaten Sleman tergantung dari ketersediaan air pada jaringan irigasi sehingga dibutuhkan data tentang kondisi jaringan irigasi dan informasi terkait yang diperlukan. Informasi dapat dihasilkan dari perancangan sistem informasi geografis yang bertujuan untuk mendapatkan detail data jaringan irigasi dan lokasi mana saja yang dapat dijadikan sebagai sumber air. Sistem informasi geografis dibuat agar masyarakat dapat mengetahui wilayah-wilayah yang terdapat pembangunan jaringan pemanfaatan air yang tersebar di wilayah tertentu khususnya di daerah kabupaten Sleman. Perancangan dan implementasi sistem dibuat guna memberikan solusi tentang manfaat sistem informasi geografi sebagai alat bantu dalam melakukan pemetaan wilayah irigasi dan memberikan perkiraan pembagian air untuk wilayah pertanian dan perikanan di Kabupaten Sleman Propinsi Daerah Istimewa Yogyakarta dalam bentuk visualisasi pemetaan wilayah berbasis sistem informasi geografi. Hasil dari penelitian ini adalah berupa Sistem Informasi Geografis berbasis web untuk mengelola data irigasi guna pembagian debit air di wilayah Kabupaten Sleman.
\end{abstract}

Kata kunci :Debit Air, Inventarisasi Irigasi, Sistem Informasi Geografi.

\section{PENDAHULUAN}

Jaringan irigasi adalah saluran, bangunan dan bangunan pelengkapnya merupakan satu kesatuan yang diperlukan untuk penyediaan, pembagian, pemberian, penggunaan dan pembuangan air irigasi. Potensi wilayah kabupaten Sleman pada bidang pertanian dan perikanan cukup tinggi, oleh karena itu untuk mempertahankan potensinya tersebut maka diperlukan suatu pengelolaan sumber daya air permukaan, yang berfungsi sebagai evaluasi, monitoring serta operasional dan pemeliharaan jaringan irigasi tersebut.

Pemerintah Daerah Kabupaten Sleman dalam hal ini Dinas Bina Marga dan Pengairan sampai dalam melakukan infentarisasi lokasi pengairan menggunakan data foto di lapangan dan di buat dalam bentuk format laporan. Kesulitan yang dihadapi oleh Dinas Bina Marga dan Pengairan adalah laporan yang di hasilkan tidak menampilkan peta lokasi saluran irigasi, pintu air di wilayah tertentu, atribut yang di tampilkan dari hasil foto dilapangan terkadang tidak sesuai dengan kondisi di lapangan, sehingga menyulitkan pengambil kebijakan untuk melakukan pengusulan perbaikan atau penambahan saluran irigasi.

Penelitian terkait dengan pengelolaan jaringan irigasi telah dilakukan sebelumnya, baik di dalam maupun di luar negeri. 1) Penelitian yang dilakukan di dalam negeri antara lain, penelitian dengan memanfaatkan sistem informasi geografi dengan tujuan utama mengetahui lekat, posisi, koordinat serta jumlah jaringan irigasi di wilayah Jawa Barat [1] dan di wilayah Rokan Hilir [2] hal ini dimaksudkan untuk pemeliharaan fasilitas jaringan irigasi di wilayah tersebut. Selain itu pemanfaatan SIG untuk melakukan pengelolaan irigasi juga dilakukan di wilayah provinsi Bengkulu, titik berat penelitian ada pada pengembangan teknologi google maps [3] tujuannya adalah bahwa dengan plugin google map pada Kementerian Pekerjaan Umum Provinsi Bengkulu dapat membantu dalam pemberian informasi kepada masyarakat tentang proyek dan aktifitas pembangunan jaringan irigasi. 
2) Penelitian yang dilakukan di luar negeri misalnya, di India mengembangkan basis data spasial untuk memperoleh manajemen pengelolaan irigasi yang efektif dalam hal efisiensi biaya operasional dengan cara melakukan penyusunan manajemen pemetaan fisik seperti drainase, geomorfologi, penggunaan lahan, kemiringan, struktur, potensi air tanah, infiltrasi air tanah, fisiografi, peta jaringan transportasi telah disiapkan dengan menggunakan citra penginderaan jauh satelit dari data IRS-LISS berdasarkan data peta spasial [4]. Penelitian lain memiliki fokus pada metode dan teknik pengelolaan irigasi, drainase, perencanaan masa tanam petani, dan bekerja sama dengan lembaga pemerintah untuk model pertanian cerdas (smart agriculture) dapat menggunakan media pemetaan yang dihasilkan analisis geospasial [5]. Fokus lain penelitian yaitu pada perencanaan pengelolaan sumber daya air yang tersedia yang menyebabkan ketidakseimbangan antara kebutuhan air yang meningkat dan ketersediaan air yang terbatas [6]. Penelitian lain di Maroko memiliki fokus terhadap penilaian indikator relevan peningkatan hasil pertanian, indikator yang dinilai berupa jaringan irigasi yang dikaitkan dengan kesesuaian lahan dengan konsep pengambilan keputusan dengan 4 parameter berupa; tekstur tanah, suhu, penggunaan lahan, dan kemiringan lereng, dengan hasil penilaian berupa prosentase "sangat sesuai", "sesuai:, "tidak sesuai", dan "sangat tidak sesuai" [7].

Pada tinjauan penelitian sebelumnya, secara detail belum ada fokus penelitian pada pemanfaatan SIG untuk pengelolaan debit air pada jaringan irigasi sehingga hal ini perlu pengembangan lebih lanjut.

Oleh karena itu penulis melakukan penelitian untuk melakukan inventarisasi saluran irigasi dengan metode pendekatan Sistem Informasi Geografis yang dimanfaatkan untuk menampilkan persebaran jaringan sungai yang digunakan sebagai saluran irigasi, serta sebagai dukungan dalam pembagian debit air antar wilayah di Kabupaten Sleman. Sistem Informasi Geografis ini dapat digunakan secara interaktif dan dapat dimanipulasi sesuai dengan kebutuhan. SIG dapat digunakan untuk memudahkan dalam pelaksanaan pekerjaan yang berkaitan dengan pengelolaan, monitoring, dan pemeliharaan saluran pengairan di wilayah Kabupaten Sleman.

Selama ini proses pembuatan peta saluran irigasi dilakukan dengan menggambarkan peta wilayah pada gambar dua dimensi. Hal ini memungkinkan untuk dibuat ke dalam peta digital yang diakses melalui halaman web. Pada penelitian ini mengusulkan salah satu alternatif pemecahan permasalahan dengan cara membuat sistem inventarisasi data irigasi dengan visualisasi peta lokasi pengairan yang terdapat di Kabupaten Sleman.

\section{Kajian Teori}

Pada sub bab kajian teori pembahasan terdiri dari 2 aspek yaitu dari sisi perangkat lunak Sistem Informasi Geografi dan penerapannya pada jaringan irigasi.

\section{Perangkat Lunak Sistem Informasi Geografi}

Sebuah software GIS harus menyediakan fungsi dan tool yang mampu melakukan penyimpanan data, analisis dan menampilkan informasi geografis. Dengan demikian, elemen yang harus terdapat dalam komponen software GIS adalah:

1. Tool untuk melakukan input dan transformasi data geografis

2. Sistem Manajemen Basis Data (DBMS)

3. Tool yang mendukung query geografis, analisis dan visualisasi

4. Graphical User Interface (GUI) untuk memudahkan akses pada tool geografi.

Data dalam SIG dikelompokkan dalam dua bagian, yaitu data spasial dan data non spasial. Data spasial merupakan data yang memuat tentang lokasi suatu objek dalam peta berdasarkan posisi geografi objek tersebut di dalam bumi dengan menggunakan sistem koordinat. Data spasial mempunyai dua elemen dasar, antara lain:

1. Lokasi

Lokasi umumnya mengacu pada letak geografi suatu objek dalam sistem koordinat bumi, akan tetapi kode geografi lainnya juga dapat dipergunakan. Sebagai contoh, kode pos.

\section{Atribut}

Data atribut adalah gambaran data yang terdiri atas informasi yang relevan terhadap suatu lokasi, seperti kedalaman, ketinggian, lokasi penjualan. Sumber-sumber data spasial termasuk peta kertas, diagram, dan scan suatu gambar atau bentuk digitalnya ke dalam sistem.

Hingga saat ini, secara umum, persepsi manusia mengenai data spasial dapat direpresentasikan dalam dua bentuk, yaitu model data vektor dan model data raster. Sumber Data spasial dapat dihasilkan dari berbagai macam sumber, diantaranya adalah : Citra Satelit, Peta Analog, Foto Udara (Aerial Photographs), Data Tabular, Data Survei (Pengamatan atau pengukuran dilapangan).

Data non spasial adalah data yang merepresentasikan aspekaspek deskriptif dari fenomena yang dimodelkannya. Data ini sering disebut juga data atribut. Dalam suatu peta, atribut biasanya disajikan sebagai teks atau legenda peta. Data spasial menggunakan raster dan vektor dalam mencatat model lokasinya, sedangkan informasi yang menjelaskan informasi spasial tersebut disebut data nonspasial (atribut). Pada sistem raster, simbol lokasinya berbentuk grid cell dalam sebuah matriks, sedangkan pada vektor simbol lokasinya menggunakan titik, garis atau polygon. 


\section{Saluran Irigasi}

Saluran irigasi adalah saluran bangunan dan pelengkap yang merupakan satu kesatuan yang diperlukan untuk penyediaan, pembagian, pemberian, penggunaan dan pembuangan air irigasi [8]. Ada tiga jenis saluran irigasi yaitu:

\section{Saluran Irigasi Primer}

Saluran irigasi primer adalah bagian dari jaringan irigasi yang terdiri dari bangunan utama, saluran induk/primer, saluran pembuangannya, bangunan bagi, bangunan bagisadap dan bangunan pelengkapnya. Saluran irigasi primer merupakan saluran irigasi utama yang membawa air masuk kedalam saluran sekunder. Air yang sudah masuk kedalam irigasi sekunder akan diteruskan ke saluran irigasi tersier. Bangunan saluran irigasi primer umumnya bersifat permanen yang sudah dibangun oleh pemerintah Daerah Kabupaten Sleman melalui Dinas Bina Marga dan Pengairan.

\section{Saluran Irigasi Sekunder}

Saluran irigasi sekunder adalah bagian dari jaringan irigasi yang terdiri dari, saluran pembuangannya, saluran bagi, bangunan bagi, bangunan bagi-sadap dan bangunan pelengkapnya. Saluran yang membawa air dari saluran primer ke petak-petak tersier yang dilayani oleh saluran sekunder tersebut. Batas ujung saluran ini adalah pada bangunan sadap terakhir. Fungsi dari saluran irigasi sekunder ini adalah membawa air yang berasal dari saluran irigasi primer dan diteruskan ke saluran irigasi tersier.

\section{Saluran Irigasi Tersier}

Saluran irigasi tersier terdiri dari beberapa petak kuarter, masing-masing seluas kurang lebih 8 sampai dengan 15 hektar. Petak tersier sebaiknya berbatasan langsung dengan saluran sekunder atau saluran primer. Sedapat mungkin dihindari petak tersier yang terletak tidak secara langsung di sepanjang jaringan saluran irigasi utama, karena akan memerlukan saluran muka tersier yang membatasi petak-petak tersier lainnya.

\section{METODOLOGI PENELITIAN}

Penelitian dilakukan untuk membuat inventarisasi data menggunakan sistem informasi geografis untuk mendukung pembagian debit air di wilayah kabupaten Sleman. Penelitian dilakukan dengan membagi ke dalam 2 tahap yaitu:

1. Tahap inisialisasi data spasial wilayah kabupaten Sleman dan data non spasial berupa data bendungan, data saluran irigasi dan data lokasi.

2. Tahap integrasi data spasial dan non spasial. Visualisasi data pemetaan irigasi wilayah kabupaten Sleman.

Untuk lebih jelasnya desain penelitian dapat dilihat pada Gambar 1.

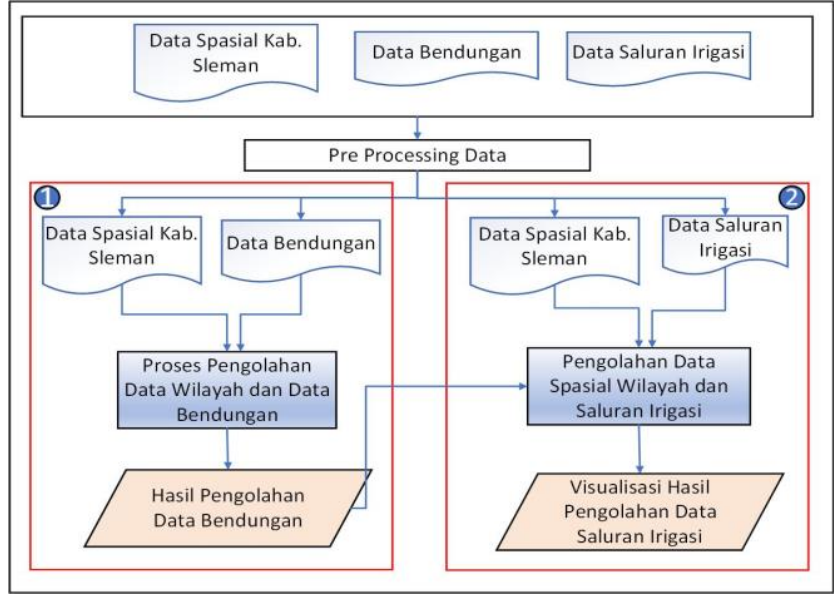

Gambar 1. Desain Penelitian

\section{Analisis Kebutuhan Fungsional}

Analisis kebutuhan fungsional pada sistem ini adalah sebagai berikut:

1. Sistem mampu memfasilitasi pendataan saluran irigasi dan bendungan yang berada di wilayah Kabupaten Sleman.

2. Sistem mampu menampilkan peta lokasi saluran irigasi dan bendungan.

3. Sistem dapat memberikan informasi perkiraan debit air pada saluran irigasi dan bendungan.

\section{Kebutuhan Data}

Kebutuhan data yang ada dalam penelitian ini adalah berupa data saluran irigasi, data bendungan dan lokasi bendungan wilayah Kabupaten Sleman.

\section{Perancangan Basis Data}

Perancangan basis data pada penelitian ini dapat dilihat pada Gambar 2.

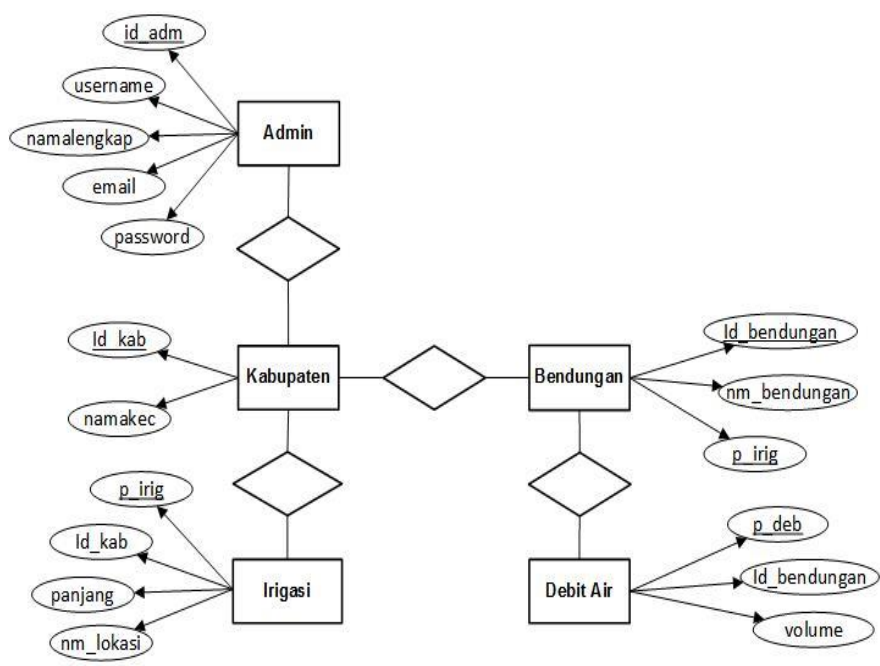




\section{Gambar 2. Entity Relationship Diagram}

Pada Gambar 2 terdapat 5 (lima) entitas dalam sistem yaitu, admin, kabupaten, irigasi, bendungan dan debit air. Adapun aturan bisnis yang digunakan adalah sebagai berikut:

1. Satu bendungan dapat terhubung ke beberapa saluran irigasi.

2. Satu saluran irigasi memiliki satu volume debit air.

3. Admin berhak menginputkan lokasi bendungan, saluran irigasi dan detail nama lokasi.

\section{Perancangan Sistem}

Perancangan sistem menggunakan diagram aliran data (DFD, Data Flow Diagram). Rancangan sistem inventarisasi saluran irigasi diimplementasikan dengan menggunakan web.

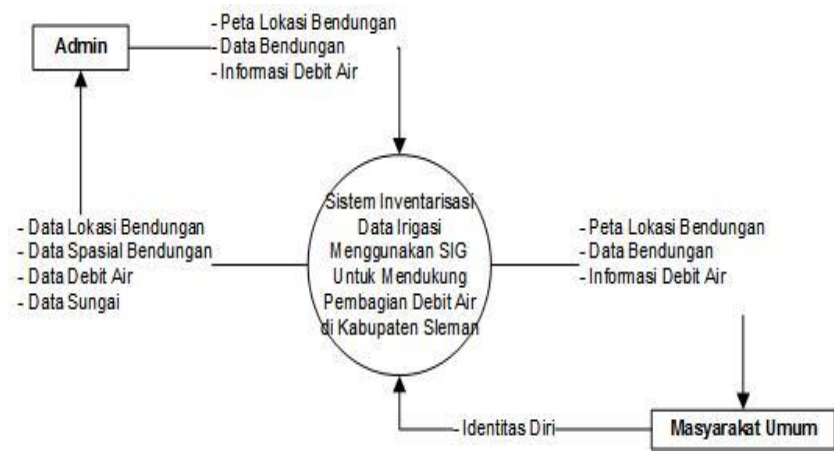

Gambar 3. Konteks Diagram

Gambar 3 merupakan rancangan konteks diagram. Entitas luar Admin bertugas untuk mengelola sistem, sedangkan entitas luar user dapat menggunakan sistem untuk melakukan visualisasi peta saluran irigasi. Informasi pemetaan saluran irigasi berupa: peta saluran irigasi, peta lokasi bendungan, dan perkiraan debit air.

\section{DFD Level I}

Data flow diagram level 1 terdiri dari 6 proses utama yaitu:

1. Proses pengelolaan data irigasi.

2. Proses pembuatan peta lokasi bendungan

3. Proses pengelolaan aplikasi web.

4. Proses edit data peta wilayah geografis.

5. Proses edit data spasial peta irigasi.

6. Proses edit data non spasial peta irigasi.

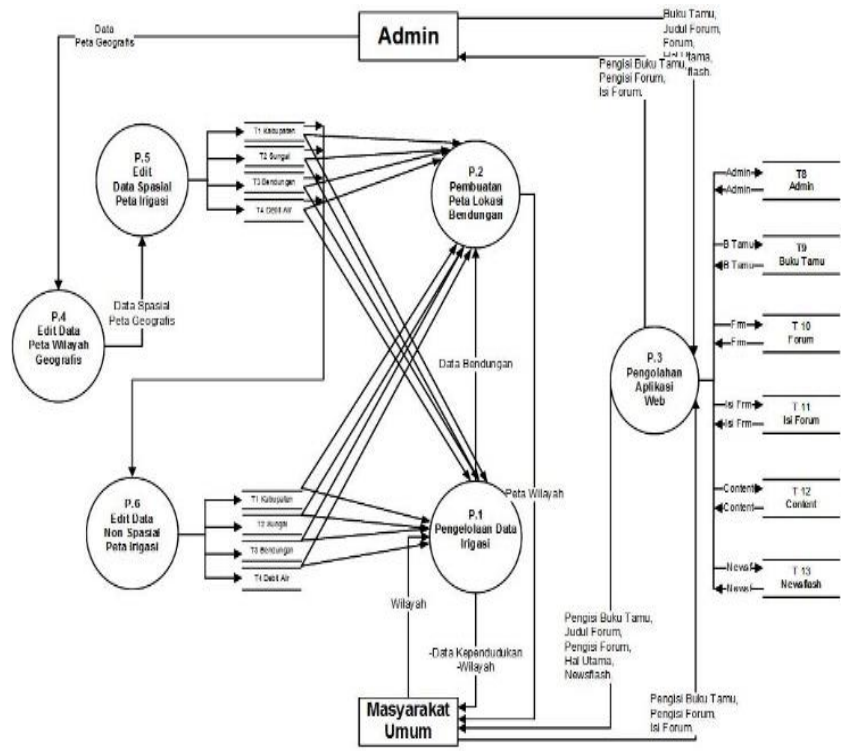

Gambar 4. DFD Level 1 Sistem Inventarisasi Data Saluran Irigasi

\section{DFD Level II}

Data flow diagram level 2 sub proses validasi memiliki 4 proses yaitu:

1. Proses validasi data administrator.

2. Proses pendataan spasial saluran irigasi.

3. Proses pendataan non spasial saluran irigasi.

4. Visualisasi peta irigasi.

Selengkapnya dapat dilihat pada Gambar 5.

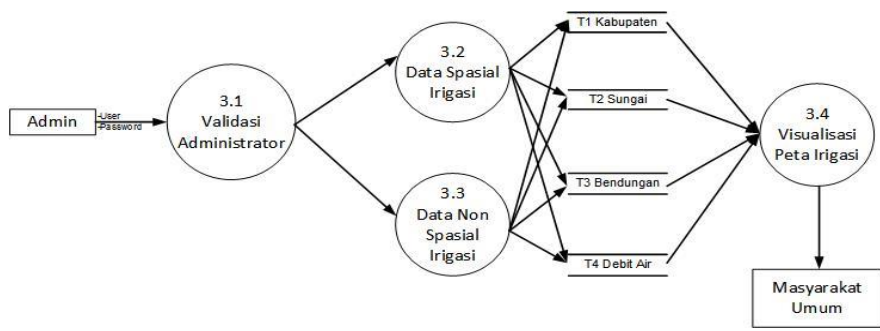

Gambar 5. DFD Level 2 Sub Proses Pengelolaan Data Saluran Irigasi

\section{Perkiraan Debit Air}

Debit air merupakan jumlah air yang mampu mencukupi kebutuhan pengariran. Jumlah debit air pada wilayah dan air yang dibutuhkan oleh suatu wilayah sehingga mampu untuk mengaliri lahan pertanian serta dapat dimanfaatkan pada lahan peternakan dan lain sebagainya, merupakan hal penting yang harus direncanakan. Perencanaan ketersediaan air irigasi di suatu wilayah digunakan analisa neraca air. Analisa neraca air merupakan perhitungan besarnya jumlah air pada berbagai fase siklus hidrologi dalam sistem DAS [9]. Neraca air merupakan gambaran potensi penyediaan air dan potensi 
kebutuhan air yang digambarkan dalam bentuk ploting data curah hujan bulanan dan nilai kebutuhan tanaman dalam suatu wilayah. Berdasarkan hasil ploting tersebut dapat ditentukan bulan-bulan yang cukup air (surplus) dan bulan-bulan kekurangan air (defisit).

Untuk mendapatkan perencanaan pengairan yang baik diperlukan kebutuhan data antara lain:

1. Penggunaan peta-peta udara dan foto (ortofoto dan peta garis) yang dilengkapi dengan garis ketinggian akan sangat besar artinya untuk perencanaan tata letak dan trase saluran.

2. Data pengukuran topografi dan saluran yang disebutkan di atas merupakan data akhir untuk perencanaan detail saluran.

3. Letak trase saluran sering dapat ditetapkan setelah membandingkan-bandingkan berbagai alternatif.

4. Letak as saluran pada silangan dengan saluran pembuang (alamiah) sering sulit ditentukan secara tepat dengan menggunakan peta topografi, sebelum diadakan pengukuran saluran.

5. Letak akhir bangunan utama dan bangunan silang tersebut hanya dapat ditentukan berdasarkan survai lapangan (dengan skala 1:200 atau 1:500).

Di wilayah Kabupaten Sleman prosedur baku pengelolaan jaringan irigasi secara umum telah dilaksanakan di, namun demikian terdapat kekurangan yaitu dalam hal pengisian blangko operasi pelaksanaan. Saat ini blangko-blangko yang masih diisi secara rutin adalah 05-0 sampai 09-0. Pada daerah irigasi ini, pergiliran pembagian air diterapkan pada saat terjadi kekurangan air (faktor K lebih kecil dari 0,7). Periode giliran yang diterapkan adalah berdasarkan hari pasaran dalam kalender Jawa dengan giliran per desa. Untuk dapat menghitung perkiraan debit air yang dibutuhkan diperlukan parameter sebagai berikut:

1. Kondisi fisik jaringan irigasi

2. Debit tersedia [10]

$$
\begin{aligned}
\mathrm{Q} & =1,70 \mathrm{BH}^{3 / 2} \\
\text { Dimana: } & \\
\mathrm{Q}= & \text { Debit tersedia }\left(\mathrm{m}^{3} / \mathrm{dt}\right) \\
\mathrm{B} & =\text { Lebar alat ukur }(\mathrm{m}) \\
\mathrm{H} & =\text { Tinggi air di hulu }(\mathrm{m})
\end{aligned}
$$

3. Debit Kebutuhan

\begin{tabular}{rll}
$\mathrm{Q}$ & \multicolumn{1}{c}{ NFR $\times \mathrm{A}$} \\
Dimana: & \\
$\mathrm{NFR}=$ & $\begin{array}{l}\text { Satuan kebutuhan air tanaman } \\
(\mathrm{lt} / \mathrm{dt} / \mathrm{ha})\end{array}$ \\
$\mathrm{A}$ & $=$ & Luas lahan (ha)
\end{tabular}

$\mathrm{A}=$ Luas lahan (ha)
4. Kehilangan Air

$$
\begin{aligned}
\mathrm{Q}_{\text {hilang }}= & \mathrm{Q}_{\text {input }}\left(\mathrm{m}^{3} / \mathrm{dt}\right)- \\
& \mathrm{Q}_{\text {output }}\left(\mathrm{m}^{3} / \mathrm{dt}\right)
\end{aligned}
$$

5. Faktor K

$$
\begin{aligned}
& K \\
& =\frac{Q_{\text {tersedia }}-Q_{\text {hilang }}}{Q_{\text {diperlukan }}}
\end{aligned}
$$

Wilayah kabupaten Sleman memiliki jenis jaringan irigasi berupa, 1) Saluran Irigasi Primer, 2) Saluran Irigasi Sekunder, 3) Saluran Irigasi Primer Pembawa, dan 4) Saluran Irigasi Tersier. Terdapat 12 buah embung, 346,8 km saluran irigasi primer, 421,4 km saluran irigasi sekunder, 1.960,9 km saluran tersier, dan 1.579 buah pintu air. Daerah irigasi wilayah Kabupaten Sleman memiliki sumber saluran berupa saluran irigasi daerah Grembyangan (Lintas Kabupaten Sleman Kabupaten Bantul), embung Jetis Suruh (Kabupaten Sleman), daerah Irigasi Bantul, embung Balecatur.

\section{HASIL DAN PEMBAHASAN}

Untuk memenuhi kriteria keberhasilan implementasi sistem, diperlukan sistem yang mampu memenuhi kebutuhan antara lain:

1. Sistem mampu menampilkan peta saluran irigasi di wilayah Kabupaten Sleman.

2. Sistem mampu memberikan perkiraan debit air pada salah satu saluran irigasi.

\section{Visualisasi Peta Saluran Irigasi}

Visualisasi peta saluran irigasi dapat dilihat pada Gambar 6 . Peta tersebut berfungsi sebagai penunjuk lokasi inventarisasi saluran irigasi di wilayah Kabupaten Sleman. Menu ini merupakan menu utama dari sistem inventarisasi data saluran irigasi.

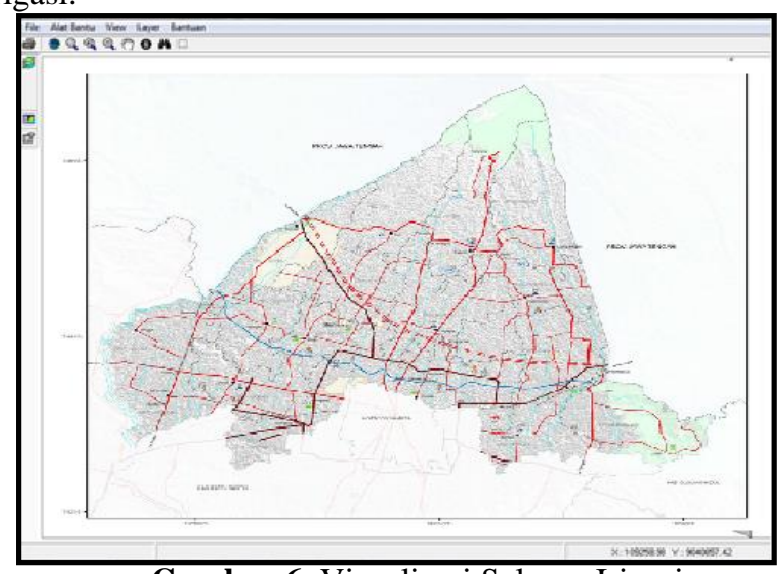

Gambar 6. Visualisasi Saluran Irigasi 


\section{Visualisasi Data Peta}

Visualisasi data peta digunakan untuk menampilkan peta apakah dalam bentuk vektor atau dalam bentuk citra satelit. Pada sistem inventarisasi data saluran irigasi ini peta yang ditampilkan adalah dalam bentuk vektor. Untuk lebih jelasnya dapat lihat pada Gambar 7.

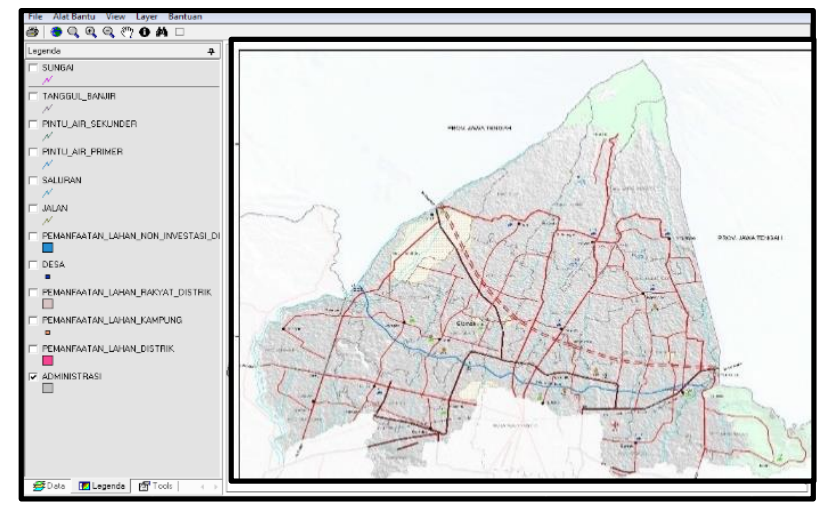

Gambar 7. Visualisasi Legenda Peta

Gambar 8 menunjukkan visualisasi jaringan irigasi yang dilakukan proses perbesaran skala peta. Data yang digunakan untuk proses pada Gambar 8 berisikan informasi jaringan irigasi di Kabupaten Sleman, yang dikategorikan berdasarkan jenis saluran. Data bersumber dari dari Balai Besar Wilayah Sungai Serayu - Opak Tahun 2019, dan Dinas PUPKP Kabupaten Sleman Tahun 2019.

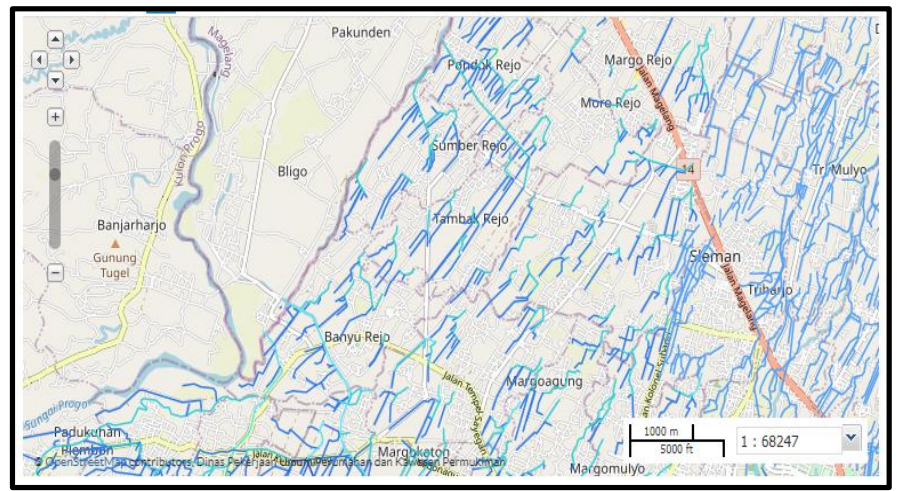

Gambar 8. Visualisasi Saluran Irigasi Menggunakan Fasilitas Zoom In

\section{KESIMPULAN}

Kesimpulan yang bisa diambil dari penelitian ini adalah sebagai berikut, 1) Aplikasi sistem inventarisasi prasarana pengairan yang dibuat dapat menampilkan pengelolaan irigasi secara lengkap di Kabupaten Sleman antara lain dapat menampilkan peta wilayah administrasi, peta saluran irigasi, peta pintu air primer, peta pintu air sekunder, peta tanggul penahan banjir dan peta jalan. 2) Laporan yang dihasilkan oleh aplikasi sistem inventarisasi data saliran irigasi melalui data atribut untuk setiap peta sesuai dengan data yang ada di lapangan dan bersifat dinamis dapat diubah sesuai pembaharuan data peta.

\section{UCAPAN TERIMA KASIH}

Penulis menyampaikan terima kasih kepada Pusat Penelitian dan Pengabdian Masyarakat Universitas Respati Yogyakarta telah mendanai pelaksanaan Penelitian Hibah Internal Tahun 2020

\section{REFERENSI}

[1]. Oktavianti O, Subari S, Yulius E. Pemetaan Jaringan Irigasi Daerah Jawa Barat Berbasis Sistem Informasi Geografis (Sig). Bentang. 2014;2(1):262527.

[2] Bakti IR. Sistem Informasi Geografis Jaringan Irigasi Dinas Bina Marga Dan Pengairan Kabupaten Rohil. Jursima. 2019;7(1):12.

[3] Ernawati, Liza Yulianti ES. Sistem Informasi Geografis Pembangunan Jaringan Irigasi Di Provinsi Bengkulu Berbasis Website Menggunakan Google Map. Media Infotama. 2014;10(2):89-96.

[4] Chaitanya MG. Spatial Data Base Creation For Effective Irrigation Management: A Model Study. 2016;11(2):383-97.

[5] Ojo OI, Ilunga F. Geospatial Analysis for Irrigated Land Assessment, Modeling and Mapping. Multipurposeful Appl Geospatial Data. 2018;

[6] Khan Mohammadi N. A Review on GIS in Irrigation and Water Management. 2019;8(05):854-7. Diambil dari: www.ijert.org

[7] Seif-Ennasr M, Bouchaou L, El Morjani ZEA, Hirich A, Beraaouz EH, Choukr-Allah R. Gis-based land suitability and crop vulnerability assessment under climate change in chtouka ait baha, morocco. Atmosphere (Basel). 2020;11(11).

[8] Sidharta, 1997, "Irigasi dan Bangunan Air “" Gunadarma, Jakarta.

[9] Susanto, S. 2012. Pengembangan dan Manajemen Sumberdaya Air di Wilayah Tropis. Penerbit Kanisius, Yogyakarta.

[10] Kartosapoetro, Sutedjo. 1997. Teknik Pengairan Pertanian. Bumi Aksara, Jakarta. 